\title{
Influence of microfiltration and adjunct culture on quality of Domiati cheese
}

\author{
S. Awad, ${ }^{1}$ N. Ahmed, and M. El Soda \\ Department of Dairy Science and Technology, Faculty of Agriculture, Alexandria University, Alexandria, Egypt
}

\begin{abstract}
The effects of microfiltration and pasteurization processes on proteolysis, lipolysis, and flavor development in Domiati cheese during 2 mo of pickling were studied. Cultures of starter lactic acid bacteria isolated from Egyptian dairy products were evaluated in experimental Domiati cheese for flavor development capabilities. In the first trial, raw skim milk was microfiltered and then the protein:fat ratio was standardized using pasteurized cream. Pasteurized milk with same protein:fat ratio was also used in the second trial. The chemical composition of cheeses seemed to be affected by milk treatmentmicrofiltration or pasteurization-rather than by the culture types. The moisture content was higher and the $\mathrm{pH}$ was lower in pasteurized milk cheeses than in microfiltered milk cheeses at $\mathrm{d} 1$ of manufacture. Chemical composition of experimental cheeses was within the legal limits for Domiati cheese in Egypt. Proteolysis and lipolysis during cheese pickling were lower in microfiltered milk cheeses compared with pasteurized milk cheeses. Highly significant variations in free amino acids, free fatty acids, and sensory evaluation were found among the cultures used in Domiati cheesemaking. The cheese made using adjunct culture containing Lactobacillus delbrueckii ssp. lactis, Lactobacillus paracasei ssp. paracasei, Lactobacillus casei, Lactobacillus plantarum, and Enterococcus faecium received high scores in flavor acceptability. Cheeses made from microfiltered milk received a higher score in body and texture compared with cheeses made from pasteurized milk.
\end{abstract}

Key words: Domiati cheese, microfiltration, adjunct culture, pasteurization

\section{INTRODUCTION}

Domiati cheese is the major cheese variety in Egypt. It differs from other pickled varieties by the fact that a very high concentration of salt (up to $12 \%$ ) is added directly to the raw cheese-milk (Abou-Donia, 2007), rather than at the end of the process to the cheese

Received August 15, 2009.

Accepted January 26, 2010.

${ }^{1}$ Corresponding author: sameh111eg@yahoo.com curd. Traditional Domiati cheese had been made from raw milk for a long time; thus, different groups of microorganisms are present in the cheese, some of which participate in flavor and texture development and some of which may be pathogenic or cause defects in cheese (El-Baradei et al., 2007). Pasteurization of milk is recommended before cheese making to improve the hygienic quality of cheese. This has a negative effect on the natural flora present in raw milk and changes some of the physicochemical properties of the milk. Weak curd is obtained when salted pasteurized milk is used in cheese making (Awad et al., 2001).

Microfiltration (MF) constitutes an alternative to heat treatment to reduce the presence of bacteria and improve the microbiological safety of dairy products without modifying the physicochemical properties of milk. Microfiltration is the passage of the product under relatively low pressure (approximately $100 \mathrm{kPa}$ ) through a semipermeable membrane with pore sizes ranging from 0.2 to $5 \mu \mathrm{m}$ (Olesen and Jensen, 1989). As bacteria generally range from 1 to $3 \mu \mathrm{m}$, under some circumstances, MF should be able to completely remove bacteria from the fluid permeate. Microfiltration might provide a lower temperature option, and thus, a less-pronounced cooked flavor than pasteurization processing for extended shelf-life dairy products, and no calcium chloride should be added to MF milk for cheese making because MF milk receives a lower load of heat treatment.

Microfiltration has been shown to be effective in reducing the number of bacteria in skim milk (Kelly and Tuohy, 1997). Reduction in total bacteria of 2.8 $\log$ (Hoffmann et al., 1996) has been reported for the Bactocatch microfiltration process (Tetra Pak Filtration Systems A/S, Aarhus, Denmark). Microfiltration utilizing a $1.4-\mu \mathrm{m}$ membrane enables complete removal of somatic cells from skim milk (Giffel and van der Horst, 2004). Olesen and Jensen (1989) found that the initial content of Bacillus cereus spores in milk had a significant effect on the content of spores in MF milk, but that the concentration ratio of milk and circulation pressure had no effects under the conditions studied.

McSweeney et al. (1993) found no differences between Cheddar cheese made from pasteurized milk and that made from MF milk. However, Beuvier et al. (1997) 
concluded that MF reduced the total amount of bacteria more effectively than pasteurization and that facultative heterofermentative lactobacilli grew more slowly in cheese made from pasteurized milk. The observed sensory differences in the cheeses were attributable to the various treatments. Skeie and Ardo (2000) showed that cheeses made from raw, pasteurized, or MF milk influenced the profiles of free amino acids in a Goudatype cheese.

Because MF reduces microorganisms more effectively than pasteurization (Kelly and Tuohy, 1997), the lactobacilli associated with good quality cheese are probably also removed. Adjunct cultures are nonstarter lactic acid bacteria, consisting mainly of lactobacilli, which are used in addition to a standard starter to enhance the flavor of cheese (El Soda et al., 2000). Lactic acid bacteria have been isolated from traditional Egyptian dairy products (El-Soda et al., 2003), and the influence of theses bacteria on the quality of Ras cheese has been investigated (Awad et al., 2007). Much research has been published to improve the quality of Domiati cheese made from pasteurized milk using selected starter cultures (El-Koussy et al., 1976; Ahmad et al., 1978; Abou-Donia, 1981; Abd-El-Khalek et al., 2008).

The objective of the present work was to study the effect of milk treatment (pasteurization vs. microfiltration) and the addition of starter culture and freezeshocked adjunct cultures on texture and flavor of Domiati cheese during pickling.

\section{MATERIALS AND METHODS}

\section{Starter Cultures}

Commercial lactic culture (DVS R704, Chr. Hansen Laboratory, Hørsholm, Denmark), contained Lactococcus lactis ssp. lactis and Lactococcus lactis ssp. cremoris and was used as the starter culture.

\section{Adjunct Culture}

Adjunct cultures of Lactobacillus delbrueckii ssp. lactis, Lactobacillus paracasei ssp. paracasei, Lactobacillus plantarum, Lactobacillus rhamnosus, Lactobacillus casei, and 3 strains of Enterococcus faecium were obtained from the collection of Faculty of Agriculture, Alexandria University (El-Soda et al., 2003). Enterococci strains were examined for hemolytic activity before use in cheese making. The adjunct cultures were grown and the cells were harvested, washed, and freeze-shocked as described earlier (Awad et al., 2007). Two mixtures of attenuated strains were used in this study. The first mixture contained L. rhamnosus, L. delbrueckii ssp. lactis, L. plantarum, and 2 E. faecium strains. The second mixture contained L.delbrueckii ssp. lactis, L. paracasei ssp. paracasei, L. casei, L. plantarum, and E. faecium. The 2 mixtures were adjusted to 1 OD (optical density at $650 \mathrm{~nm}$ ) in $\mathrm{pH} 7.0$ phosphate buffer (Awad et al., 2007 ) and used at levels of $0.5,1.5$, or $2 \mathrm{~mL} / \mathrm{kg}$ of milk.

Commercial adjunct culture (DVS CR401, Chr. Hansen Laboratory) containing L. delbrueckii ssp. lactis, L. paracasei ssp. paracasei, and Lactobacillus helveticus was used at a level of $0.0275 \mathrm{~g} / \mathrm{kg}$ of milk.

\section{Milk}

Raw whole cow and buffalo milks were obtained from the dairy farm at Alexandria University. A mixture of 70:30 of raw cow and buffalo milk (fat: $4.5 \%$; acidity: 0.16 to $0.17 \%$ as lactic acid) was used in this study. Raw milk was skimmed $(<0.05 \%$ fat $)$ in mechanical separator (Alfa-Laval, Tumba, Sweden).

\section{Treatment of Cheese Milk}

Pasteurization. The skim milk and cream were pasteurized using a high-temperature short-time technique in a tubular heat exchanger (Actini, Evian, France). The heat treatment used was $74^{\circ} \mathrm{C}$ and $15 \mathrm{~s}$ for skim milk and $78^{\circ} \mathrm{C}$ and $15 \mathrm{~s}$ for cream, followed by quick cooling to $35^{\circ} \mathrm{C}$. Pasteurized skim milk was mixed with pasteurized cream to obtain the closest initial level of milk fat (4.4-4.5\%).

Microfiltration. Raw skim milk was microfiltered using microfiltration unit (Alfa-Laval) with a ceramic membrane pore size of $1.4 \mu \mathrm{m}$, membrane area of $0.2 \mathrm{~m}^{2}$, flow rate of $150 \mathrm{~L} / \mathrm{h}$ per $\mathrm{m}^{2}$, and temperature of $50^{\circ} \mathrm{C}$. Cold pasteurized skim milk (MF) was mixed with pasteurized cream to obtain the closest initial level of milk fat $(4.4-4.5 \%)$.

\section{Cheese Making Procedure}

Three replicates of experimental Domiati cheeses for each treatment were processed using computercontrolled cheese equipment (INRA, Poligny, France) equipped with four 11-L vats. Seven treatments of Domiati cheeses were made from pasteurized milk and another 7 treatments from MF milk. The 4 vats and these treatments were rotated for each replication to reduce systematic errors. Calcium chloride solution was added at a rate of $0.2 \mathrm{~g} / \mathrm{kg}$ of pasteurized milk just before adding the starter culture. Starter cultures (DVS R704, $0.15 \mathrm{~g} / \mathrm{kg}$ ) and different doses of freezeshocked suspensions of adjunct cultures $(0.5,1$, or 2 $\mathrm{mL} / \mathrm{kg}$ ) were added individually to milk at $35^{\circ} \mathrm{C}$, and DVS CR401 adjunct culture was added at a level of 
$0.0275 \mathrm{~g} / \mathrm{kg}$. The inoculated milk was held for $1 \mathrm{~h}$, and $\mathrm{NaCl}$ was added to each vat at level of $12 \%$ (wt/wt). A suitable amount of commercial calf rennet was added to coagulate the milk for $90 \mathrm{~min}$. The curd was then transferred to stainless steel molds lined with cheesecloth. After 2 to $3 \mathrm{~h}$, a plate and weights $(2-2.5 \mathrm{~kg}$ for each $10 \mathrm{~kg}$ of cheese milk) were placed to compact the curd. The weights were removed after 4 to $6 \mathrm{~h}$ and the cheese mass was divided with a knife into blocks of about $9 \times 9 \times 9 \mathrm{~cm}$, each weighing 450 to $500 \mathrm{~g}$. The cheese blocks were then arranged in cans that were filled with pasteurized $\left(65^{\circ} \mathrm{C} / 30 \mathrm{~min}\right)$ brine $(12 \%$ salt $)$. The cans were closed and stored at room temperature (20 to $25^{\circ} \mathrm{C}$ ) for $60 \mathrm{~d}$.

\section{Cheese Composition Analysis}

Total protein was measured by the Kjeldahl method (AOAC, 2000) and fat content by the Gerber method (AOAC, 2000). A Corning flat surface combination electrode was used to measure the $\mathrm{pH}$ on the wellmixed ground cheese samples. The moisture content was determined using the moisture analyzer (model HR73, Mettler Toledo, Toledo, OH). Salt content was determined using a chloride meter (Jenway, Dunmow, UK).

\section{Microbiological Analysis}

Cheese samples $(10 \mathrm{~g})$ were homogenized for $4 \mathrm{~min}$ with $90 \mathrm{~mL}$ of a sterile $2 \%$ sodium citrate solution and serially diluted using sterile $0.05 \%$ peptone. Appropriate dilutions of milk and sodium citrate solution of cheese were plated on plate count agar for enumerating total microbial count at $32^{\circ} \mathrm{C}$ for $2 \mathrm{~d}$, violet red bile agar for enumerating coliform bacteria at $37^{\circ} \mathrm{C}$ for $2 \mathrm{~d}$, potato dextrose agar for the enumeration of yeasts and molds at room temperature $\left(20-25^{\circ} \mathrm{C}\right)$ for $5 \mathrm{~d}$, and staphylococci 110 Medium for enumeration of staphylococci at $37^{\circ} \mathrm{C}$ for $2 \mathrm{~d}$ (Difco's Manual, 1985).

\section{Assessment of Proteolysis and Lipolysis}

The water-soluble extract (WSE) was prepared by the method developed by Kuchroo and Fox (1982), and free amino acids (FAA) were determined in WSE by using the Cd-ninhydrin method of Folkertsma and Fox (1992) and expressed as millimolar leucine equivalents in WSE by using a standard curve. Free fatty acids were determined by the method of Deeth et al. (1975) and expressed as millimolar equivalents per gram of cheese fat.

\section{Sensory Evaluation}

Sensory evaluation was carried out at the Department of Dairy Science and Technology, Alexandria University, by a panel consisting of 15 cheese graders, including staff members and assistants, cheese producers, and consumers. Each individual was given 3 blocks $(6 \times 2 \times 2 \mathrm{~cm})$ of cheese per sample. Samples were presented in identical plastic sample cups sealed with plastic lids and identified by a random 3-digit number. The coded samples were randomly presented. The graders were asked to give the cheese an overall grade out of 100, to evaluate whether each sample was typical Domiati cheese, and to provide additional comments. Cheeses were graded at $60 \mathrm{~d}$ of age and the following scale was used: $0-25=$ unacceptable; $26-50=$ poor; 51-75 = acceptable; $76-100=$ good.

\section{Statistical Analysis}

Data reported are the average of 3 measurements. The SAS software package (SAS Institute, 1999) was used for ANOVA. Differences were considered significant at $P<0.05$.

\section{RESULTS AND DISCUSSION}

\section{Removal of Bacteria with Microfiltration and Pasteurization}

Across 3 replicates, total bacterial counts of raw skim milk were reduced from $150,000 \mathrm{cfu} / \mathrm{mL}$ to 250 and $1 \mathrm{cfu} / \mathrm{mL}$ by pasteurization and MF treatments, respectively. Microfiltration achieved an average $5.18 \mathrm{log}$ reductions, and pasteurization of whole milk achieved an average $2.78 \log$ reduction (Table 1 ). The log reduction in bacterial count caused by MF was comparable to that reported by Maubois (1997). Both coliforms and staphylococci were reduced to undetectable levels by $\mathrm{MF}$ and pasteurization.

\section{Cheese Composition}

Table 2 shows that the Domiati cheeses made from pasteurized milk contained more moisture than cheeses made from MF milk at $\mathrm{d} 1$ of manufacture. The MF milk cheese received a lower load of heat treatment than the pasteurized milk cheese. Minor protein denaturation resulting from pasteurization could explain the higher moisture in cheese from pasteurized milk. Similar results showing the effect of pasteurization and microfiltration of milk on the moisture content of 
Table 1. Effect of microfiltration and pasteurization on microbiological content $\left(\log _{10} \mathrm{cfu} / \mathrm{mL}\right)$ of raw skim milk

\begin{tabular}{|c|c|c|c|c|c|}
\hline Milk & Total bacterial count & Coliform count & Staphylococcus spp. & Yeast & Molds \\
\hline Raw milk & 5.18 & 3.51 & 2.81 & 3.40 & $\mathrm{ND}^{1}$ \\
\hline Pasteurized milk & 2.40 & ND & ND & ND & ND \\
\hline Microfiltered milk & ND & ND & ND & ND & ND \\
\hline
\end{tabular}

${ }^{1} \mathrm{ND}=$ not detected.

cheese have been reported by McSweeney et al. (1993) and Skeie et al. (2001).

The moisture in all cheeses significantly decreased during pickling. Most of the moisture losses occurred during the first $30 \mathrm{~d}$ of pickling. The cultures used in this study had little or no effect on the moisture content of Domiati cheese. The average moisture content of Domiati cheeses at d 1 of manufacture is comparable to that reported by Awad et al. (2001).

The fat and protein content in cheeses were found to be related to the moisture content in cheeses during pickling. The protein and fat content on a DM basis were not significantly different $(P<0.05)$ in all cheeses (Table 2). There was a gradual increase in salt in moisture content during the pickling period (Table 2); similar results were reported by Awad et al. (2001).

The gross chemical composition of aged Domiati cheese was in agreement with the typical composition of Domiati cheese (Abd El-Salam and Alichanidis, 2004) and was within the legal limit for Domiati cheese in Egypt (Egyptian Standards, 2000).

\section{Viability of Total Bacteria in Cheese During Pickling}

The total bacterial count was higher in pasteurized milk cheeses than in MF milk cheeses throughout the pickling period (Table 3). The higher bacterial count in pasteurized milk cheese is related to the microbial content of the milk used and the moisture content in cheese (Tables 1 and 2). Total bacterial count can have significant effects on the extent of proteolysis and sensory attributes. Coliform bacteria, staphylococci, yeasts, and molds were not detected in any cheese samples during pickling.

A gradual decline in total bacterial count was seen during pickling in all cheeses, resulting in about a 2.5 $\log$ reduction after $2 \mathrm{mo}$. The results were in agreement with those reported by other authors (El-Koussy et al., 1976; Ahmad et al., 1978; Abou-Donia, 1981; Abd-ElKhalek et al., 2008), which found a decline in the viable bacterial counts during Domiati cheese pickling.

The reduction of total bacterial count during picking of Domiati cheese occurred at a higher rate in cheeses

Table 2. Mean chemical composition (\%) of cheese made from pasteurized (Past) and microfiltered (MF) milk and evaluated after 1, 30 , or 60 d of pickling

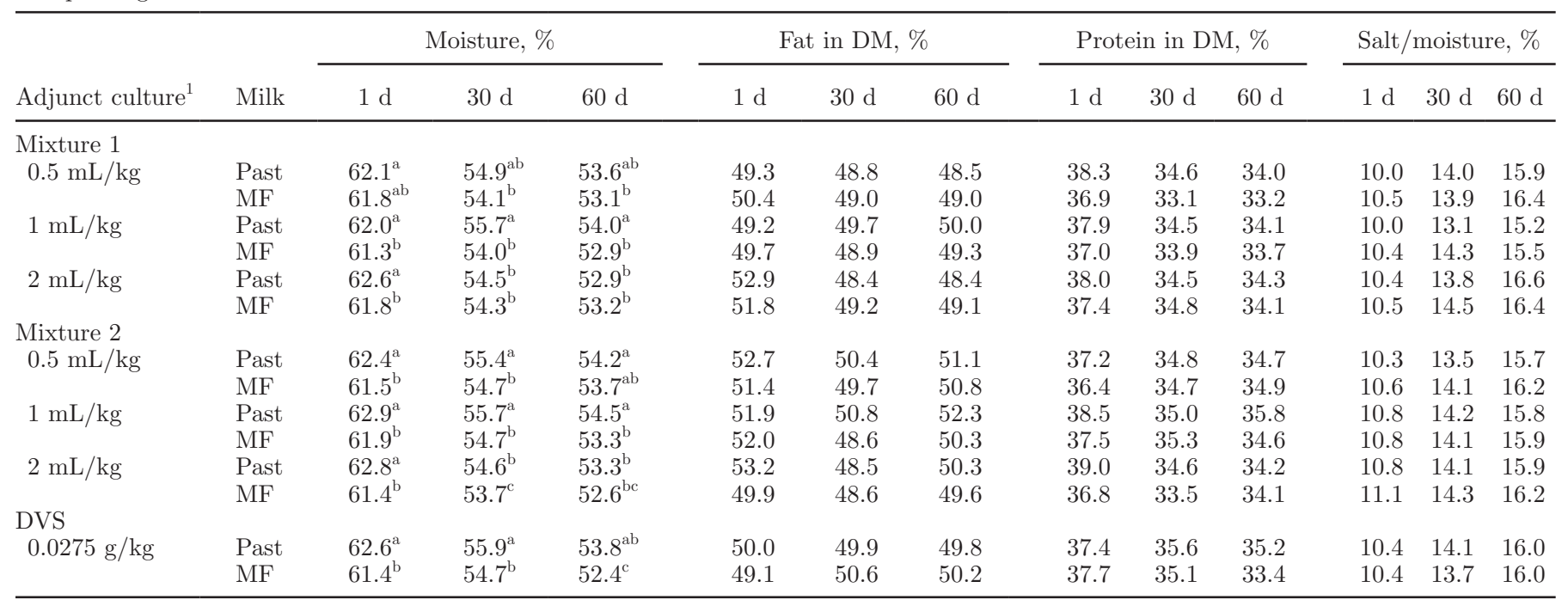

\footnotetext{
${ }^{\mathrm{a}-\mathrm{c}}$ Means within a column with no common superscript differ $(P<0.05)$.
}

${ }^{1}$ Mixture 1 contained Lactobacillus rhamnosus, Lactobacillus delbrueckii ssp. lactis, Lactobacillus plantarum, and 2 Enterococcus faecium; mixture 2 contained L. delbrueckii ssp. lactis, Lactobacillus paracasei ssp. paracasei, Lactobacillus casei, L. plantarum, and E. faecium; DVS CR401 (Chr. Hansen, Hørsholm, Denmark) contained L. delbrueckii ssp. lactis, L. paracasei ssp. paracasei, and Lactobacillus helveticus. 
Table 3. Bacterial populations $\left(\log _{10} \mathrm{cfu} / \mathrm{g}\right)$ in Domiati cheese made from pasteurized (Past) or microfiltered (MF) milk during pickling for 1,30 , or $60 \mathrm{~d}$

\begin{tabular}{|c|c|c|c|c|}
\hline \multirow[b]{2}{*}{ Adjunct culture $^{1}$} & \multirow[b]{2}{*}{ Milk } & \multicolumn{3}{|c|}{$\begin{array}{l}\text { Viability of total bacteria } \\
\text { during pickling }\end{array}$} \\
\hline & & $1 \mathrm{~d}$ & $30 \mathrm{~d}$ & $60 \mathrm{~d}$ \\
\hline \multicolumn{5}{|l|}{ Mixture 1} \\
\hline \multirow[t]{2}{*}{$0.5 \mathrm{~mL} / \mathrm{kg}$} & Past & $7.96^{\mathrm{b}}$ & $6.58^{\mathrm{a}}$ & $5.40^{\mathrm{a}}$ \\
\hline & $\mathrm{MF}$ & $7.59^{\mathrm{c}}$ & $6.28^{\mathrm{b}}$ & $4.22^{\mathrm{c}}$ \\
\hline \multirow[t]{2}{*}{$1 \mathrm{~mL} / \mathrm{kg}$} & Past & $7.98^{\mathrm{b}}$ & $6.62^{\mathrm{a}}$ & $5.03^{\mathrm{a}}$ \\
\hline & $\mathrm{MF}$ & $7.76^{\mathrm{c}}$ & $6.29^{\mathrm{b}}$ & $4.65^{\mathrm{c}}$ \\
\hline \multirow[t]{2}{*}{$2 \mathrm{~mL} / \mathrm{kg}$} & Past & $8.46^{\mathrm{a}}$ & $6.75^{\mathrm{a}}$ & $5.53^{\mathrm{a}}$ \\
\hline & $\mathrm{MF}$ & $7.76^{\mathrm{c}}$ & $6.51^{\mathrm{b}}$ & $5.37^{\mathrm{a}}$ \\
\hline \multicolumn{5}{|l|}{ Mixture 2} \\
\hline \multirow[t]{2}{*}{$0.5 \mathrm{~mL} / \mathrm{kg}$} & Past & $7.88^{\mathrm{b}}$ & $6.66^{\mathrm{a}}$ & $5.46^{\mathrm{a}}$ \\
\hline & $\mathrm{MF}$ & $7.59^{\mathrm{c}}$ & $6.32^{\mathrm{b}}$ & $4.76^{\mathrm{b}}$ \\
\hline \multirow[t]{2}{*}{$1 \mathrm{~mL} / \mathrm{kg}$} & Past & $7.76^{\mathrm{c}}$ & $6.59^{\mathrm{a}}$ & $5.58^{\mathrm{a}}$ \\
\hline & $\mathrm{MF}$ & $7.65^{c}$ & $6.56^{\mathrm{ab}}$ & $5.48^{\mathrm{a}}$ \\
\hline \multirow[t]{2}{*}{$2 \mathrm{~mL} / \mathrm{kg}$} & Past & $7.90^{\mathrm{b}}$ & $6.61^{\mathrm{a}}$ & $5.29^{\mathrm{a}}$ \\
\hline & $\mathrm{MF}$ & $7.73^{\mathrm{c}}$ & $6.30^{\mathrm{b}}$ & $4.88^{\mathrm{b}}$ \\
\hline \multirow{3}{*}{$\begin{array}{l}\text { DVS } \\
0.0275 \mathrm{~g} / \mathrm{kg}\end{array}$} & & & & \\
\hline & Past & $7.87^{\mathrm{b}}$ & $6.44^{\mathrm{b}}$ & $4.96^{\mathrm{b}}$ \\
\hline & MF & $7.61^{\mathrm{c}}$ & $6.13^{\mathrm{c}}$ & $4.52^{\mathrm{c}}$ \\
\hline
\end{tabular}

made from MF milk compared with cheeses made from pasteurized milk (Table 3 ). The higher reduction rate of viable bacterial count in MF cheeses may be related to the low moisture content in MF cheeses compared with pasteurized milk cheeses.

\section{Cheese pH During Pickling}

The $\mathrm{pH}$ values of experimental cheeses determined during pickling are presented in Table 4 . The $\mathrm{pH}$ values on d 1 of manufacture of cheeses made using MF milk were higher than those in cheeses made using pasteurized milk. The lower $\mathrm{pH}$ values in pasteurized milk cheeses compared with MF cheeses were related to viable bacterial count and moisture content in cheeses (Tables 2 and 3 ). The $\mathrm{pH}$ values of cheeses on $\mathrm{d} 1$ of manufacture were dependent on adjunct culture doses, because the $\mathrm{pH}$ value was reduced with increasing culture doses.

The lower $\mathrm{pH}$ in cheeses made from pasteurized milk than in cheeses from MF milk is in accordance with the findings of Beuvier et al. (1997). Skeie and Ardo (2000) reported that the total amounts of organic acids, especially of lactic acid, were higher in cheeses made from pasteurized milk than in those made from MF milk.

During cheese ripening, starter and nonstarter lactic acid bacteria continue to produce acids and alkaline proteolytic products (Abd El-Salam and Alichanidis, 2004). pH can be a measure to observe the shifts in the balance between proteolysis and acid production. The $\mathrm{pH}$ of all cheeses decreased $(P<0.05)$ gradually throughout the pickling period. During the first week or two, starter bacteria ferment the residual lactose and reduce $\mathrm{pH}$ (Choisy et al., 2000). At all pickling times, cheeses made with $2 \mathrm{~mL} / \mathrm{kg}$ of adjunct culture had significantly $(P \leq 0.05)$ lower $\mathrm{pH}$ values than the rest of the treatments.

\section{Proteolysis}

Release of amino acids ( $\mathrm{m} M$ leucine equivalents) in WSE of experimental cheeses at different pickling stages is shown in Table 4. The FAA values were higher in cheeses made using pasteurized milk than in cheeses made using MF milk throughout the pickling period. This finding is related to factors such as high moisture content, low $\mathrm{pH}$ values, high variable bacterial count, and higher residual chymosin activity. Chymosin activity is also related to high amount of rennet used for coagulation and the high moisture content in pasteurized milk cheeses compared with MF milk cheeses. Free amino acids increased with increasing amounts of added adjunct culture and were higher in cheeses made with adjunct cultures at $2 \mathrm{~mL} / \mathrm{kg}$ than in cheeses made with $1 \mathrm{~mL} / \mathrm{kg}$. Free amino acids increased significantly $(P<$ $0.05)$ as pickling progressed in all cheeses. The major contributors to the production of small peptides and FAA are probably the starter and nonstarter bacterial 
Table 4. Biochemical and organoleptic properties of experimental Domiati cheese made from pasteurized (Past) or microfiltered (MF) milk and evaluated after pickling for 1,30 , or $60 \mathrm{~d}$

\begin{tabular}{|c|c|c|c|c|c|c|c|c|c|c|c|c|}
\hline \multirow[b]{2}{*}{ Adjunct culture $^{1}$} & \multirow[b]{2}{*}{ Milk } & \multicolumn{3}{|c|}{$\mathrm{pH}$ value } & \multicolumn{3}{|c|}{ Free AA } & \multicolumn{3}{|c|}{ FFA } & \multicolumn{2}{|c|}{$\begin{array}{c}\text { Sensory evaluation } \\
\text { at } 60 \mathrm{~d}\end{array}$} \\
\hline & & $1 \mathrm{~d}$ & $30 \mathrm{~d}$ & $60 \mathrm{~d}$ & $1 \mathrm{~d}$ & $30 \mathrm{~d}$ & $60 \mathrm{~d}$ & $1 \mathrm{~d}$ & $30 \mathrm{~d}$ & $60 \mathrm{~d}$ & Flavor & $\begin{array}{l}\text { Body } \\
\text { and texture }\end{array}$ \\
\hline \multicolumn{13}{|l|}{ Mixture 1} \\
\hline \multirow[t]{2}{*}{$0.5 \mathrm{~mL} / \mathrm{kg}$} & Past & $6.24^{\mathrm{b}}$ & $5.24^{\mathrm{b}}$ & $4.11^{\mathrm{c}}$ & $0.032^{\mathrm{b}}$ & $0.13^{\mathrm{c}}$ & $0.23^{\mathrm{b}}$ & $0.53^{\mathrm{d}}$ & $1.16^{\mathrm{c}}$ & $1.89^{\mathrm{bc}}$ & $78^{\mathrm{e}}$ & $73^{\mathrm{d}}$ \\
\hline & MF & $6.33^{\mathrm{a}}$ & $5.47^{\mathrm{a}}$ & $4.35^{\mathrm{a}}$ & $0.029^{\mathrm{bc}}$ & $0.11^{\mathrm{d}}$ & $0.19^{\mathrm{c}}$ & $0.46^{\mathrm{e}}$ & $0.95^{\mathrm{d}}$ & $1.63^{\mathrm{d}}$ & $74^{\mathrm{f}}$ & $83^{\mathrm{b}}$ \\
\hline \multirow{2}{*}{$2 \mathrm{~mL} / \mathrm{kg}$} & Past & $6.21^{\mathrm{b}}$ & $5.18^{\mathrm{b}}$ & $4.02^{\mathrm{d}}$ & $0.035^{\mathrm{b}}$ & $0.18^{\mathrm{b}}$ & $0.29^{\mathrm{b}}$ & $0.96^{\mathrm{a}}$ & $1.86^{\mathrm{a}}$ & $2.13^{\mathrm{b}}$ & $87^{\mathrm{b}}$ & $80^{c}$ \\
\hline & MF & $6.27^{\mathrm{b}}$ & $5.32^{\mathrm{a}}$ & $4.26^{\mathrm{b}}$ & $0.032^{\mathrm{b}}$ & $0.15^{\mathrm{c}}$ & $0.27^{\mathrm{b}}$ & $0.72^{\mathrm{b}}$ & $1.23^{\mathrm{b}}$ & $1.87^{\mathrm{bc}}$ & $83^{c}$ & $86^{\mathrm{b}}$ \\
\hline \multicolumn{13}{|l|}{ Mixture 2} \\
\hline \multirow[t]{2}{*}{$0.5 \mathrm{~mL} / \mathrm{kg}$} & Past & $6.23^{\mathrm{b}}$ & $5.20^{\mathrm{b}}$ & $4.10^{\mathrm{c}}$ & $0.033^{\mathrm{b}}$ & $0.14^{\mathrm{c}}$ & $0.27^{\mathrm{b}}$ & $0.51^{\mathrm{d}}$ & $1.11^{\mathrm{c}}$ & $1.75 \mathrm{c}$ & $83^{\mathrm{c}}$ & $80^{\mathrm{c}}$ \\
\hline & MF & $6.29^{\mathrm{b}}$ & $5.27^{\mathrm{a}}$ & $4.31^{\mathrm{b}}$ & $0.032^{\mathrm{b}}$ & $0.12^{\mathrm{d}}$ & $0.25^{\mathrm{b}}$ & $0.45^{\mathrm{e}}$ & $0.98^{\mathrm{d}}$ & $1.64^{\mathrm{d}}$ & $74^{\mathrm{f}}$ & $84^{\mathrm{b}}$ \\
\hline \multirow[t]{2}{*}{$1 \mathrm{~mL} / \mathrm{kg}$} & Past & $6.14^{\mathrm{c}}$ & $5.11^{\text {bc }}$ & $4.00^{\mathrm{d}}$ & $0.043^{\mathrm{a}}$ & $0.23^{\mathrm{a}}$ & $0.32^{\mathrm{a}}$ & $0.72^{\mathrm{b}}$ & $1.16^{\mathrm{c}}$ & $1.98^{\mathrm{b}}$ & $82^{\mathrm{d}}$ & $78^{\mathrm{c}}$ \\
\hline & MF & $6.21^{\mathrm{b}}$ & $5.20^{\mathrm{b}}$ & $4.15^{\mathrm{c}}$ & $0.033^{\mathrm{b}}$ & $0.20^{\mathrm{b}}$ & $0.30^{\mathrm{ab}}$ & $0.62^{\mathrm{c}}$ & $1.01^{\mathrm{d}}$ & $1.78^{\mathrm{c}}$ & $75^{\mathrm{f}}$ & $84^{\mathrm{b}}$ \\
\hline
\end{tabular}

${ }^{\mathrm{a}-\mathrm{f}}$ Means within a column with no common superscript differ $(P<0.05)$.

${ }^{1}$ Mixture 1 contained Lactobacillus rhamnosus, Lactobacillus delbrueckii ssp. lactis, Lactobacillus plantarum, and 2 Enterococcus faecium; mixture 2 contained L. delbrueckii ssp. lactis, Lactobacillus paracasei ssp. paracasei, and Lactobacillus casei, L. plantarum, and E. faecium; DVS CR401 (Chr. Hansen, Hørsholm, Denmark) contained L. delbrueckii ssp. lactis, L. paracasei ssp. paracasei, and Lactobacillus helveticus.

enzymes (El Soda et al., 2000). Differences were observed among the cheeses made using different strains and doses of adjunct culture, indicating that the adjunct culture seems to be responsible for the production of FAA in Domiati cheese during ripening. The second mixture of adjunct culture produced a higher level of FAA than first mixture. On the other hand, both mixtures of adjunct cultures isolated from Egyptian dairy products produced more FAA during Domiati cheese pickling than did the DVS adjunct culture. This finding may be related to the proteolytic system of wild lactic acid bacteria used in this study. The production of a high level of FAA in cheese made with added adjunct culture containing $E$. faecium can be attributed to the high tolerance of enterococci to salt and acid during cheese ripening (Litopoulou-Tzanetaki, 1990; Wessels et al., 1990) and the production of proteolytic enzymes involved in casein degradation (Bahay-El-Din et al., 2002).

\section{Lipolysis}

The lipolysis in Domiati cheese during pickling was measured in terms of total FFA (expressed as $\mathrm{m} M$ equivalents/g of cheese fat). Free fatty acids increased gradually with increasing pickling period (Table 4). Cheeses made from pasteurized milk showed higher acid values during pickling than cheeses made from MF milk. However, cheeses containing mixture 2 of adjunct cultures exhibited a higher acid value than did those containing mixture 1 and DVS cultures. High acid values in cheeses containing enterococci strains may be attributed to the release of intracellular esterases and lipases (Bahay-El-Din et al., 2002; Giraffa, 2003).

Commonly, acid values follow the same trend as soluble nitrogen, suggesting that factors affecting proteolysis may have a similar effect on lipolysis (Kebary et al., 1996). Higher values of FAA and FFA were recorded in cheese made using pasteurized milk and using $2 \mathrm{~mL} / \mathrm{kg}$ of adjunct culture containing mixture 2 . These results indicated that adjunct cultures contribute to lipolysis in cheese, and greater lipolysis was found in pasteurized milk cheese than in MF cheeses.

\section{Sensory Assessment of Cheese}

The mean grades for flavor intensity and body and texture acceptability of cheeses at $60 \mathrm{~d}$ of pickling are shown in Table 4. Generally, the pasteurized milk cheeses received higher flavor intensity scores than MF milk cheeses, but both aged cheeses were considered acceptable. High scores for Domiati cheese flavor were noticed in aged cheeses made from pasteurized milk with $2 \mathrm{~mL} /$ $\mathrm{kg}$ of adjunct culture containing $L$. delbrueckii ssp. lactis, L. paracasei ssp. paracasei, L. casei, L. plantarum, and E. faecium. This might because of their relatively higher levels of free amino groups and FFA. Concentrations of low molecular weight peptides and FAA have 
considerable influence on the cheese flavor (El Soda, 1993; Awad, 2006). In addition, the concentration of FFA, especially short-chain FFA, is responsible for the characteristic cheese flavor (Kanawjia et al., 1995).

Panelists detected differences $(P<0.05)$ in body and texture between pasteurized and MF milk cheeses (Table 4). The MF cheeses received higher scores for overall body and texture than did the pasteurized milk cheeses. The MF cheeses made using $2 \mathrm{~mL} / \mathrm{kg}$ of adjunct culture containing $L$. delbrueckii ssp. lactis, $L$. paracasei ssp. paracasei, L. casei, L. plantarum, and E. faecium received the highest overall scores in body and texture acceptability. The main goal of this research was to produce Domiati cheese with high microbiological quality and similar textural and flavor characteristics to its raw milk counterpart. Because the MF milk contained a low level of nonstarter lactic acid bacteria that gave the best results, traditional Domiati cheese flavor did not develop in MF cheese made with a low dose of adjunct culture. On the other hand, pasteurization of milk reduced the body and texture acceptability of Domiati cheese.

\section{CONCLUSIONS}

It is concluded from the present study that MF milk yielded Domiati cheeses with a lower amount of rennet needed for coagulation, lower bacterial count, lower moisture content, higher $\mathrm{pH}$, slower proteolysis and lipolysis, and increased body and texture acceptability of resultant cheese compared with pasteurized milk. Adding freeze-shocked adjunct cultures of $L$. delbrueckii ssp. lactis, L. paracasei ssp. paracasei, L. casei, L. plantarum, and E. faecium isolated from Egyptian dairy products produced significantly higher amounts of FAA and FFA and contributed to Domiati cheese flavor. Therefore, to obtain a Domiati cheese with typical flavor and texture, it will be of considerable interest to use a combination of MF milk and adjunct cultures. The beneficial role of enterococci in the development of cheese aroma led to inclusion of selected enterococcal strains in certain starter cultures for Domiati cheese. Further work is in progress to establish the possible use of E. faecium in commercial starter preparation.

\section{ACKNOWLEDGMENTS}

This work was supported in part by the Egyptian Ministry of Agriculture and the Bureau de liaison Franco-Egyptien (BLAFE).

\section{REFERENCES}

Abd-El-Khalek, A. B., O. M. Sharaf, K. El-Shafei, and A. N. Abosereh., 2008. Improving the quality of Domiati cheese using genetically modified Lactobacillus casei ssp. casei. Egypt. J. Dairy Sci. 36:239-248.

Abd El-Salam, M. H., and E. Alichanidis. 2004. Cheese Varieties Ripened in Brine. Pages 227-249 in Cheese. Chemistry, Physics and Microbiology. Vol. 2. 3rd ed. P. F. Fox, P. L. H. McSweeney, T. M. Cogan, and T. P. Guinee, ed. Elsevier, London, UK.

Abou-Donia, S. A. 1981. Pasteurisation and addition of starter to milk for Domiati cheese. Indian J. Dairy Sci. 34:136-145.

Abou-Donia, S. A. 2007. Recent development in Egyptian Domiati research: An overview. Egypt. J. Dairy Sci. 35:1-14.

Ahmad, M., Riaz-ur-Rehman, and A. G. Khan., 1978. Effect of salt concentration and lactic starter in the manufacture of Domiati cheese. J. Agric. Res. Pakistan 16:241-246.

AOAC. 2000. Official Methods of Analysis. Association of Official Analytical Chemists, International, Arlington, VA

Awad, S. 2006. Texture and flavor development in Ras cheese made from raw and pasteurized milk. Food Chem. 97:394-400.

Awad, S., N. H. Ahmed, and M. El Soda. 2007. Evaluation of isolated starter lactic acid bacteria in Ras cheese ripening and flavor development. Food Chem. 104:1192-1199.

Awad, S. A., Y. I. Abdel-Kader, and M. A. Nawar. 2001. The quality of white pickled cheese as affected with the types of calcium salt. Mansoura Univ. J. Agric. Sci. 26:2183-2203.

Bahay-El-Din, B. B., M. El-Soda, and N. Ezzat. 2002. Proteolytic, lipolytic and autolytic activities of enterococci strains isolated from Egyptian dairy products. Lait 82:289-304.

Beuvier, E., K. Berthaud, S. Cegarra, A. Dasen, S. Pochet, S. Buchin and G. Duboz. 1997. Ripening and quality of Swiss-type cheese made from raw, pasteurized or microfiltered milk. Int. Dairy J. 7:311-323.

Choisy, C., M. Desmazeaud, J. C. Gripon, G. Lambert, and J. Lenoir. 2000. The biochemistry of ripening. Pages $82-154$ in Cheesemaking: From Science to Quality Assurance. A. Eck and J. C. Gillis, ed. Lavoisier Publishing, Paris, France.

Deeth, C. H., C. H. Fitz-Gerald, and A. F. Wood. 1975. A convenient method for determining the extent of lipolysis in milk. Aust. J. Technol. 30:109-111.

Difco's Manual. 1985. Dehydrated Culture Media and Reagents for Microbiology. 10th ed. Difco Laboratories Inc., Detroit, MI.

Egyptian Standards. 2000. Soft cheese: Part 1, ES: 1-1008. Ministry of Industry and Technological Development, Cairo, Egypt.

El-Baradei, G., A. Delacroix-Buchet, and J. Ogier. 2007. Biodiversity of bacterial ecosystems in traditional Egyptian Domiati cheese. Appl. Environ. Microbiol. 73:1248-1255.

El-Koussy, L. A., A. M. Hamdy, M. A. Nasr, and A. O. AbdelGhani. 1976. Utilization of starter in Domiati cheesemaking. Milchwissenschaft 31:428-430.

El Soda, M. 1993. Control and enhancement of flavor in cheeses. Pages 219-246 in Microbiology and Biochemistry of Cheese and Fermented Milk. B. Law, ed. Blackie Academic Professional, London, UK.

El-Soda, M., M. El-Ziney, S. Awad, G. Osman, N. Omran, G. Gamal, N. Ezzat, and H. El-Shafei. 2003. A culture collection of lactic acid bacteria isolated from raw milk and traditional Egyptian dairy products. Egypt. J. Dairy Sci. 31:23-41.

El Soda, M., S. A. Madkor, and P. S. Tong. 2000. Adjuncts cultures: recent developments and potential significance to cheese industry. J. Dairy Sci. 83:609-619.

Folkertsma, B., and P. F. Fox. 1992. Use of the cadmium-ninhydrin reagent to assess proteolysis in cheese during ripening. J. Dairy Res. 59:217-224.

Giffel, M. C., and H. C. van der Horst. 2004. Comparison between bactofugation and microfiltration regarding efficiency of somatic cell and bacteria removal. Bull. IDF 389: 49-53. IDF, Brussels, Belgium.

Giraffa, G. 2003. Functionality of enterococci in dairy products. Int. J. Food Microbiol. 88:215-222.

Hoffmann, W., H. Klobes, Chr. Kiesner, G. Suhren, U. Krusch, I. Clawin-Radecker, and P. H. Larsen. 1996. Use of microfiltration for the production of pasteurized milk with extended shelf life. Bull. IDF 311:45-46. IDF, Brussels, Belgium. 
Kanawjia, S. K., P. Rajesh, L. Sabikhi, and S. Singh. 1995. Flavor, chemical and texture profile changes in accelerated ripened Gouda cheese. Lebensm. Wiss. Technol. 28:577-583.

Kebary, K. M. K., A. E. Khader, A. N. Zedan, and S. F. Mahmoud. 1996. Accelerated ripening of low fat Ras cheese by attenuated lactobacilli cells. Food Res. Int. 29:705-713.

Kelly, P. M., and J. J. Tuohy. 1997. The effectiveness of microfiltration for the removal of microorganisms. Bull. IDF 320:26-31. IDF, Brussels, Belgium.

Kuchroo, C. N., and P. F. Fox. 1982. Soluble nitrogen in Cheddar cheese. Comparison of extraction procedures. Milchwissenschaft $37: 331-335$.

Litopoulou-Tzanetaki, E. 1990. Changes in numbers and kinds of lactic acid bacteria during ripening of Kefalotyri cheese. J. Food Sci. 55:111-113.

Maubois, J. 1997. Current uses and future perspectives of MF technology in the dairy industry. Bull. IDF. 320:37-39. IDF, Brussels, Belgium.
McSweeney, P. L. H., P. F. Fox, J. A. Lucey, K. N. Jordan, and T. M. Cogan. 1993. Contribution of the indigenous microflora to the maturation of Cheddar cheese. Int. Dairy J. 3:613-634.

Olesen, N., and F. Jensen. 1989. Microfiltration: The influence of operation parameters on the process. Milchwissenschaft 44:476479.

SAS Institute. 1999. User's Guide: Statistics. Version 8 ed. SAS Inst. Inc., Cary, NC.

Skeie, S., and Y. Ardo. 2000. Ripening study of model cheeses made from raw, pasteurized and microfiltered milk. Food Sci. Technol. 33:499-505.

Skeie, S., C. Lindbergb, and J. Narvhusa. 2001. Development of amino acids and organic acids in Norvegia, influence of milk treatment and adjunct Lactobacillus. Int. Dairy J. 11:399-411.

Wessels, D., P. J. Jooste, and J. F. Mostert. 1990. Technologically important characteristics of Enterococcus isolates from milk and dairy products. Int. J. Food Microbiol. 10:349-352. 